\title{
WATANIC JURISPRUDENCE: ARTICULATING THE LEGITIMATE ELEMENTS OF THE BASIC STRUCTURE OF THE FEDERAL CONSTITUTION
}

\author{
Wan Ahmad Fauzi Wan Husain*
}

\begin{abstract}
The doctrine of the basic structure of a constitution would be undisputable if those elements thereunder are clear and representing the facts of our local history, nationhood, and the principle of the rule of law. Former Chief Justice Tun Abdul Hamid Mohamad argued that the doctrine of the basic structure of a constitution introduced by the Indian Supreme Court contradicts Article 159 of the Federal Constitution and beyond the competent jurisdiction of the local courts. Hence, this article puts forward the conceptual framework of the basic structure adopted by the Federal Court in the case of Indira Gandhi to articulate those elements summed therein viewed from the watanic jurisprudence. The watanic jurisprudence analyses legal documents and sources of sovereignty based upon two philosophical worldviews; continuum and dichotomous frameworks relying upon the local legal history context and the present legal provisions of a country. Depending on a broad and purposive manner in proper linguistic, philosophic, and historical contexts of the Malaysian legal historical documents, the legitimate elements of the basic structure are the principle of sovereignty as embedded in the oath of office of the Yang di-Pertuan Agong together with the matters aggregated in Article 38(4), Article 159(5) and Article 161E. The oath of the Yang di-Pertuan Agong thus legitimizes Syariah compliance as the rule of law. The Federal Constitution of Malaysia also expressly protects its basic structure with strict conditional amendments. In conclusion, the basic structure of our Federal Constitution must be viewed from our local circumstances in compliance with the principle of constitutional supremacy and the rule of law.
\end{abstract}

Keywords: Malaysian constitution, basic structure, watanic jurisprudence, sovereignty, Malay custom, local circumstances.

* Datuk Associate Professor Dr., Director, Institute of Civilization and Strategic Studies, University Malaysia Pahang (ITKAS). Email: wanfauzi@ump.edu.my. 


\title{
JURISPRUDENS WATAN: PENCERAHAN ELEMEN- ELEMEN SAH DALAM STRUKTUR ASAS PERLEMBAGAAN PERSEKUTUAN
}

\begin{abstract}
ABSTRAK
Doktrin struktur asas perlembagaan tidak akan boleh dipertikai sekiranya elemen-elemennya jelas dan mewakili fakta-fakta sebenar sejarah tempatan, kenegaraan dan prinsip kedaulatan undang-undang. Mantan Ketua Hakim Negara Tun Abdul Hamid Mohamad menghujahkan doktrin struktur asas perlembagaan yang diperkenalkan oleh Mahkamah Agung India bercanggah dengan Perkara 159 Perlembagaan Persekutuan dan melampaui bidangkuasa kompeten mahkamah tempatan. Justeru, artikel ini menggunakan kerangka konsep yang diterimapakai oleh Mahkamah Persekutuan di dalam kes Indira Gandhi untuk menyatakan elemen-elemen yang terjumlah sedemikian menurut kacamata jurisprudens watan. Jurisprudens watan menganalisis dokumen perundangan dan sumber kedaulatan berdasarkan dua pandangan hidup falsafah; kerangka kontinum dan dikotomi berlandaskan konteks sejarah perundangan tempatan begitu juga peruntukan-peruntukan undangundang semasa sebuah negara. Berlandaskan dengan cara yang luas dan purposif dalam bahasa yang betul, falsafah, dan konteks sejarah undangundang tempatan Malaysia, elemen-elemen sah struktur asas adalah prinsip kedaulatan seperti yang tertanam dalam sumpah jawatan Yang di-Pertuan Agong bersama-sama dengan perkara-perkara yang terjumlah dalam Perkara 38(4), Perkara 159(5), dan Perkara 161E. Sumpah Yang di-Pertuan Agong sekali gus mengabsahkan pematuhan Syariah sebagai prinsip kedaulatan undang-undang. Perlembagaan Persekutuan Malaysia juga jelas melindungi struktur asasnya dengan pindaan bersyarat yang ketat. Kesimpulannya, struktur asas Perlembagaan Persekutuan hendaklah dilihat daripada keadaan-keadaan tempatan sendiri selaras dengan prinsip ketinggian perlembagaan dan kedaulatan undangundang.
\end{abstract}

Kata kunci: Perlembagaan Malaysia, struktur asas Perlembagaan, jurisprudens watan, prinsip kedaulatan, adat Melayu, keadaan tempatan. 


\section{INTRODUCTION}

The doctrine of the basic structure of a constitution was imported into our legal system when the Federal Court in the case of Indira Gandhi A/P. Mutho v. Pengarah Jabatan Agama Islam Perak \& Ors and other appeals $^{l}$ adopted the decision of the Indian Supreme Court in Kesavananda Bharti v. the State of Kerala ${ }^{2}$. It was a departure from the previous two local cases as decided in Loh Kooi Choon v. The Government of Malaysia ${ }^{3}$ and Phang Chin Hock v. PP $P^{4}$ that rejected the application of such doctrine.

Zainun Ali, FCJ when delivering the judgment in Indira Gandhi on behalf of her learned ladyship's fellow judges viewed as follows:

The basic structure of a constitution is 'intrinsic to, and arises from, the very nature of a constitution'. (See Calvin Liang and Sarah Shi, 'The Constitution of Our Constitution, A Vindication of the Basic Structure Doctrine' Singapore Law Gazette (August 2014) 12). The Fundamental underlying principles and the role of the judiciary as outlined above form part of the basic structure of the constitution, being "something fundamental and essential to the political system that is established thereunder" (per Sundaresh Menon CJ in Yong Vui Kong v. Public Prosecutor [2015] SG CA 11 at [71]. It is well settled those features of the basic structure cannot be abrogated or removed by a constitutional amendment (see Kesavananda Bharti v. State of Kerala AIR 1973 SC 1461).

The aforesaid decision was criticized by the former Chief Justice Tun Abdul Hamid Mohamed ${ }^{5}$ when he argued:

In so doing, the court had usurped the power of Parliament to make law. Nowhere in the Federal Constitution does it say that certain parts of the Constitution cannot be amended. On the other hand, Article 159 very clearly states that Parliament may amend the Constitution provided the procedure for the amendment of the particular part is followed e.g., by a two-thirds majority or a twothirds majority plus the consent of the Conference of Rulers. The

\footnotetext{
[2018] MLJU 69.

AIR 1973 SC 146.

[1977] 2 MLJ 187.

[1980] 1 MLJ 70 (FC).

Tun Abdul Hamid Mohamad, Who is encroaching whose jurisdiction, Parliament or Court? No Judge Is a Parliament (Selangor: Tun Abdul Hamid bin Haji Mohamad, 2021), 243-244.
} 
power to amend the Constitution is vested in the Parliament, not the court. Yet, by adopting the principle of the basic structure of the constitution from the judgment of the Indian Supreme Court, our judges gave themselves the power to effectively amend the Constitution by deciding that Parliament has no power to amend any part of the Constitution which they will decide, on a case-by-case basis, that it cannot be amended. In other words, the judges gave themselves the power to strike down an amendment by Parliament of any part of the Constitution which they say forms parts of the basic structure of the Constitution and therefore cannot be amended.

In Loh Kooi Choon, Raja Azlan Shah FJ, (as His Royal Highness then was) had rejected the principle of the basic structure of the Constitution in Kesavananda Bharati. The learned Judge, inter alia, observed:

Whatever may be said of other Constitutions, they are ultimately of little assistance to us because our Constitution now stands in its own right and it is, in the end, the wording of our Constitution itself that is to be interpreted and applied, and this wording "can never be overridden by the extraneous principles of other Constitutions" see Adegbenro v. Akintola \& Anor [1963] 3 All ER 544 551. Each country frames its constitution according to its genius and for the good of its own society. We look at other Constitutions to learn from their experiences, and from a desire to see how their progress and well-being is ensured by their fundamental law.

The pertinent issues that arise from the application of the said doctrine are not only its legal implication but most importantly, the elements of the basic structure that the Court takes cognizance of.

Hence, the objective of this article is to articulate the legitimate elements aggregated in the basic structure of our Federal Constitution. In doing so, it is important to first define what is meant by the basic structure of a constitution. To serve the above purpose, this article would apply the conceptual framework of the basic structure as adopted by the Federal Court in the case of Indira Gandhi to examine those elements aggregated in our legal framework to give that effect.

\section{THE CONCEPTUAL LEGAL FRAMEWORK}

In the case of Indira Gandhi, the Federal Court recognized that the foundational principles of a constitution shape its basic structure. The Federal Court referred to the decision of the Canadian Supreme Court 
in Reference re Senate Reform ${ }^{6}$ to define the conceptual legal framework of the basic structure of a constitution. This article applies the same legal framework in Reference re Senate Reform in order to articulate the legitimate elements of the basic structure of the Federal Constitution.

In Reference re Senate Reform, ${ }^{7}$ defines the basic structure of a constitution as follows:

The constitution implements a structure of government and must be understood by reference to the constitutional text itself, the historical context, and previous judicial interpretations of constitutional meaning.... The rules of constitutional interpretation require that constitutional documents be interpreted in a broad and purposive manner and placed in their proper linguistic, philosophic, and historical contexts... Generally, a constitutional interpretation must be informed by the foundational principles of the constitution, which include principles such as federalism, democracy, the protection of minorities, as well as constitutionalism and the rule of law ....

These rules and principles of interpretation have led this Court to conclude that the Constitution should be viewed as having an 'internal architecture', or 'basic constitutional structure' ... The notion of architecture expresses the principles that the individual elements of the Constitutional are linked to the others, and must be interpreted by reference to the structure of the Constitution as a whole' ... In other words, the Constitution must be interpreted to discern the structure of government that it seeks to implement. The assumptions that underlie the text and the manner in our interpretation understanding and application of the text.

It is observed that there are two approaches to examine the elements of the basic structure of a constitution:

1. Referring to the constitutional text itself, its historical context, and previous judicial interpretations of constitutional meaning; and

2. Interpreting the constitutional documents in a broad and purposive manner and placed in their proper linguistic, philosophic, and historical contexts, not otherwise. 
The conceptual legal framework for the basic structure as defined in Reference re Senate Reform was not strictly followed in Indira Gandhi. It is found the Federal Court in Indira Gandhi had adopted the constitutional principles relying on the Westminster model and other Commonwealth countries as opposed to the principles laid in Section 3 of the Civil Law Act 1956 (Revised 1972). Section 3(1) of the Civil Law Act 1956 (Revised 1972) provides:

Save so far as other provision has been made or may hereafter be made by any written law in force in Malaysia, the Court shall:

(a) in Peninsular Malaysia or any part thereof, apply the common law of England and the rules of equity as administered in England on the $7^{\text {th }}$ day of April, 1956;

provided always that the said common law, rules of equity and statutes of general application shall be applied so far as the circumstances of the States of Malaya and their respective inhabitants permit and subject to such qualifications as local circumstances render necessary.

In addition, thereto, there is no deliberation on the existing laws to answer various constitutional interpretation as well legal issues before the Federal Court in Indira Ghandi. The existing laws as defined in Article 162 must be first looked into before importing foreign legal principles by virtue of Section 3 of the Civil Law Act 1956 (Revised 1972). Article 162(1) provides:

Subject to the following provisions of this Article and Article 163, the existing law shall, until repealed by the authority having power to do so under this Constitution, continue in force on and after Merdeka Day, with such modifications as may be made therein under this Article and subject to any amendments made by Federal or State law.

"Existing law" is defined in Article 162(2) as "any law in operation in the Federation or any part thereof immediately before Merdeka Day". 8 Therefore, the principles laid in Indira Gandhi must be distinguished and re-examined for future judicial decisions.

This article applies the watanic jurisprudence as a methodology to examine the legitimate elements of the basic structure of our Federal

8 Read Wan Ahmad Fauzi Wan Husain. Yang di-Pertuan Agong: Kedaulatan, Prerogatif dan Amalan (Kuala Lumpur: Dewan Bahasa dan Pustaka, 2021), 171-175. 
Constitution. The watanic jurisprudence is a school of thought that analyses legal documents and sources of sovereignty based upon two philosophical worldviews; the continuum and dichotomous frameworks relying upon local legal historical context as well as the present legal provisions to determine a legitimate constitutional system of a country or government and a valid legal interpretation that uphold the rule of law. ${ }^{9}$

Therefore, this article relies upon various local primary sources ranging from the traditional constitutions and credible documents that source our legal history together with the present constitutional provisions to achieve its objective.

\section{THE FOUNDATION OF THE MALAYSIAN FEDERALISM}

Malaysia is a federation where its constitution is the supreme law of the country. However, that does not mean the sovereignty of Malaysia is its Federal Constitution. Instead, the Federal Constitution upholds the sovereignty of the Malay Rulers as enshrined in Article 181(1). ${ }^{10}$ Sovereignty is the most important principle that determines the rule of

9 For further reading see Wan Ahmad Fauzi bin Wan Husain. Konsep Kedaulatan Watan Raja-Raja Melayu Dalam Perlembagaan Persekutuan Malaysia Menurut Sejarah Perundangan. Disertasi Ijazah Doktor Falsafah Undang-undang, Universiti Kebangsaan Malaysia, Bandar Baru Bangi, 2017; See also Wan Ahmad Fauzi Wan Husain, Konsep Kedaulatan Watan Suatu Pengenalan (Kuala Lumpur: Majlis Ittihad Ummah, 2017); Wan Ahmad Fauzi Wan Husain. Kedaulatan Raja-Raja Melayu: Jurisprudens, Governan \& Prinsip Perlembagaan Persekutuan (Selangor: Abad Sinergi Sdn. Bhd., 2018); Wan Ahmad Fauzi Wan Husain. Jurisprudens Watan Perlembagaan Persekutuan: Teks, Konteks dan Isu-isu Ketatanegaraan (Selangor: Abad Sinergi Sdn. Bhd., 2018); Wan Ahmad Fauzi Wan Husain, Kenegaraan Malaysia: Sejarah, Kedaulatan dan Kebangsaan (Perlis: Penerbit Universiti Malaysia Perlis, 2020); Wan Ahmad Fauzi Wan Husain. Yang di-Pertuan Agong: Kedaulatan, Prerogatif dan Amalan (Kuala Lumpur: Dewan Bahasa dan Pustaka, 2021).

10 Subject to the provisions of this Constitution, the sovereignty, prerogatives, powers, and jurisdiction of the Rulers and the prerogatives, powers, and jurisdiction of the Ruling Chiefs of Negeri Sembilan within their respective territories as hitherto had and enjoyed shall remain unaffected. 
law. ${ }^{11}$ The establishment of the Federation is governed by the Federation Agreement of Malaya dated 5 August, 1957.

Through the Federal Constitution, the Malay Rulers had agreed that their sovereignty which includes prerogatives, powers and jurisdiction shall be performed in accordance with the constitutional provisions, be it in the Federation and their respective states accordingly. It must be noted that the sovereignty, prerogatives, powers, and jurisdiction of the Malay Rulers were not created by the Federation Agreement of Malaya, 1957 but their sovereignty, prerogatives, powers, and jurisdiction are the ones that legitimized the establishment of Malaysia as it is today as well as the validity of our Federal Constitution itself. ${ }^{12}$ The above principle is evidenced in every State Agreement dated $21^{\text {st }}$ January 1948 signed between the nine Malay Rulers with the British Government, there is uniformed clause read as follows:

15. Sovereignty of the Ruler: The prerogatives, power and jurisdiction of His Highness within the State of Johore shall be those which His Highness the Sultan of Johore possessed on the first day of December, 1941, subject nevertheless to the provisions of the Federation Agreement and this Agreement.

An examination of Clause 6 of the Federation Agreement of Malaya dated 5 August 1957, shows that it is beyond reasonable doubt that the Federal Constitution only came into force upon the approval and by the enactment of each of the Malay States which requires the consent of the respective Malay Ruler. The express provision of Article 181(1)

11 Wan Ahmad Fauzi Wan Husain, Kedaulatan Raja-Raja Melayu: Jurisprudens, Governan \& Prinsip Perlembagaan Persekutuan (Selangor: Abad Sinergi Sdn. Bhd., 2018), p. 40-69.

12 For further reading see Wan Ahmad Fauzi Wan Husain. Jurisprudens Watan Perlembagaan Persekutuan: Teks, Konteks dan Isu-isu Ketatanegaraan (Selangor: Abad Sinergi Sdn. Bhd., 2018); See also Wan Ahmad Fauzi Wan Husain. Kedaulatan Raja-Raja Melayu: Jurisprudens, Governan \& Prinsip Perlembagaan Persekutuan (Selangor: Abad Sinergi Sdn. Bhd., 2018); Wan Ahmad Fauzi Wan Husain, Kenegaraan Malaysia: Sejarah, Kedaulatan dan Kebangsaan (Perlis: Penerbit Universiti Malaysia Perlis, 2020); Wan Ahmad Fauzi Wan Husain. Yang di-Pertuan Agong: Kedaulatan, Prerogatif dan Amalan (Kuala Lumpur: Dewan Bahasa dan Pustaka, 2021). 
further signifies the position of the Malay Rulers' sovereignty in our constitutional legal framework.

Various legal documents and historical facts evidenced that the Federation of Malaya as well as Malaysia, as it is today neither recognized the people's sovereignty nor an absolute democracy as claimed by some parties. ${ }^{13}$. This legal position is very clear in the existence of Article 38(4) and Article 159(5) that restrict the legislating powers of the Malaysian Parliament.

The Federation of Malaya, which later became Malaysia was the product of a constitutional development that evolved from the great Melaka Sultanate until the states that were previously under her territory had re-emerged as the Federation of Malaya in 1948. The structure of our federalism was built upon the following ten pillars:

1. The Malay Rulers were the ones who signed the State Agreements, 1948 as well as the Federation Agreement of Malaya, $1948^{14}$ both dated on 21 January 1948;

2. The British Government in the State Agreements, 1948 recognized the sovereignty of the Malay rulers as those of prerogatives, powers, and jurisdiction which they possessed on 1 December 1941;

3. The Federated Malay States and the Unfederated Malay States had already embraced the traditional constitutional system inherited from the Melaka Sultanate before the execution of the Federation Agreement of Malaya, 1948;

13 Wan Ahmad Fauzi Wan Husain, Kenegaraan Malaysia: Sejarah, Kedaulatan dan Kebangsaan (Perlis: Penerbit Universiti Malaysia Perlis, 2020), p. 33-47; for a more detailed read on the concept of Watanic Jurisprudence, see Wan Ahmad Fauzi Wan Husain. Kedaulatan RajaRaja Melayu: Jurisprudens, Governan \& Prinsip Perlembagaan Persekutuan (Selangor: Abad Sinergi Sdn. Bhd., 2018); Wan Ahmad Fauzi Wan Husain. Yang di-Pertuan Agong: Kedaulatan, Prerogatif dan Amalan (Kuala Lumpur: Dewan Bahasa dan Pustaka, 2021).

14 See the State Agreements, 1948 consisted of nine individual state agreements; and the Federation Agreement of Malaya, 1948 entered by the nine Malay rulers with the British Governments representing the Strait Settlements (Negeri Sembilan signed by the Yang di-Pertuan Besar and the Ruling Chiefs). 
4. Before the Federation Agreement of Malaya, 1948 (the Malayan Union was abolished and had no legal effect), the Malay states administered their own legislative, executive, and judicial powers covering in personal as well as public spheres based upon their respective structure;

5. The State Agreements, 1948 stipulated fundamental provisions for the establishment of a new federation and the modern character of a state political system for peace, order, and good government;

6. The sovereignty of the Malay Rulers placed upon themselves the constitutional responsibilities to safeguard the sanctity of Islam and their position under Malay custom as a caliph, ${ }^{15}$ as well as the manifestation of their position thereunder to protect the local elements such as Malay custom, Malay language, Jawi writing, the special position of the Malays, and legitimate interests of non-Malays being their subjects, ${ }^{16}$

7. The sovereignty of the Malay rulers as recognized in the State Agreements, 1948 gave legitimacy to the Federal Constitution of Malaya, 1957 under the Federation Agreement of Malaya dated 5 August 1957 (Negeri Sembilan signed by the Yang diPertuan Besar and the Ruling Chiefs) for an independent Federation of Malaya, free from British advisory; ${ }^{17}$

8. Those prerogatives, powers, and jurisdiction vested in the Yang di-Pertuan Agong and delegated to the Federal organs such as Cabinet Ministers, Parliament, and Judiciary were originated from the Malay states under the Federation Agreement of Malaya, 1957 and formalized by various state enactments passed by the state legislatures.

15 See Hukum Kanun Melaka, Hukum Kanun Johor, Hukum Kanun Pahang, Hukum Kanun Perak, Undang-Undang Kedah, and other written laws preMerdeka Day.

16 See the provisions in the State Agreements, 1948 and the Federation Agreement of Malaya, 1948.

17 "6. The foregoing provisions of this Agreement are conditional upon the approval of the said Federal Constitution by Federal Ordinance and by an Enactment of each the Malay States (Federation Agreement dated August $5,1957$. 
9. The Ninth Schedule of the Federal Constitution contains all powers and jurisdiction inherently originated from the respective Malay states. Those enumerated under List I (Federal List) and List III (Concurrent List) were delegated to the Yang di-Pertuan Agong as the Supreme Head of the Federation under the Federation Agreement of Malaya, 1957, and enactments passed by the respective State Legislature. Those enumerated under List-II (State List) and List III (Concurrent List) were powers and jurisdiction retained in the respective states. Those powers and jurisdiction are not yet spelled out in the Nine Schedule still reside in the respective State Legislature. ${ }^{18}$

10.The Federal Constitution of Malaysia still preserves the sovereignty of Yang di-Pertuan Agong and the Malay Rulers ${ }^{19}$ as well as other local elements as protected thereunder.

Therefore, the foundational principles of the traditional constitution that constructed federalism in Malaysia relies on the sovereignty of the Malay rulers, not democracy as envisaged in other countries that adopt a dichotomous philosophical legal framework.

\section{BASIC STRUCTURE OF THE TRADITIONAL CONSTITUTION}

Islamic law had become the law of the land of Tanah Melayu since the $15^{\text {th }}$ century and Islam has been the faith of the Malay Sultans or Rulers since then and continues until today. Islam placed the Sultan or a ruler as the shadow of Allah s.w.t, on earth or popularly known in Arabic as "khalifah" or caliph. ${ }^{20}$

18 Article 77 of the Federal Constitution.

19 Read Wan Ahmad Fauzi Wan Husain. Yang di-Pertuan Agong: Kedaulatan, Prerogatif dan Amalan (Kuala Lumpur: Dewan Bahasa dan Pustaka, 2021); Wan Ahmad Fauzi Wan Husain. Kedaulatan Raja-Raja Melayu: Jurisprudens, Governan \& Prinsip Perlembagaan Persekutuan (Selangor: Abad Sinergi Sdn. Bhd., 2018).

20 Andaya, B.W. \& Andaya, L.Y., A History of Malaysia, (Hong Kong: Macmillan Press, 1984), p. 53-55; The term "shadow" of Allah has also been used by al-Qaradhawi. See Yusuf al-Qaradhawi. 2009. Fiqh Kenegaraan. Terj. Arsil Ibrahim. (Kuala Lumpur: Blue-T Publication Sdn. Bhd., 2009), 11 said, "Allah has ordained for us to call to the right 
Risalat Hoekoem Kanoen: Jaitoe Oendang-Oendang Melaka, a version of Hukum Kanun Melaka kept in Leiden, states, "came to the time of Sultan Iskandar Shah, the first king to convert to Islam and commanded the customs and orders of the great nobles and laid down the customs and order of the state descended to his prince Sultan Muzaffar Shah and descended to his prince Sultan Mansor Shah and descended to his prince Sultan Alaeddin Riayat Shah and descended to his prince Sultan Muhammad Shah and descended to his prince Sultan Mahmud Shah khalifah mukminin zillullah fil 'alam (shadow of Allah in the universe) is one who has a custom of hokum and order"21 The present states constitution of every Malay states stipulate that a ruler must be a muslim of a Malay blood. ${ }^{22}$

The concept of the shadow of Allah s.w.t was not only spoken but expressly enshrined in the traditional constitutions in Tanah Melayu in the form of written laws such as Hukum Kanun Melaka,

and to prevent evil. Without the power of government, it is impossible for us to fulfill that obligation. Likewise, other obligations such as jihad, upholding justice, doing hajj, establishing Friday prayers, celebrating the great days of Islam, helping the persecuted, upholding hudud and others. All of these things cannot be accomplished without the existence of power and the rule of Islam. Thus, it is narrated that the sultan is the shadow of God on the earth. Even salaf scholars such as Fudhail Ibn Iyadh and Ahmad Ibn Hanbal once said, "If we had a mustajab supplication, we would pray for the sultan". The reason is, the benefit of all mankind he leads depends on his own safety".

21 “...datang kepada zaman Sultan Iskandar Shah iaitu raja yang pertama masuk agama Islam dan menitahkan adat dan perintah orang raja yang besar-besar dan meletakkan adat dan peritah negeri turun temurun kepada putera baginda Sultan Muzaffar Shah dan turun kepada putera baginda Sultan Mansor Shah dan turun kepada putera baginda Sultan Alaeddin Riayat Shah dan turun kepada putera baginda Sultan Muhammad Shah dan turun kepada putera baginda Sultan Mahmud Shah khalifah mukminin zillullah fil 'alam (shadow of Allah in the universe) ialah yang mempunyai adat hukum dan perintah" in $\mathrm{Ph}$. S. Van Ronkel. Risalat Hoekoem Kanoen: Jaitoe Oendang-Oendang Melaka (Leiden: E. J. Brill, 1919), 2-3.

22 For further reading see Constitutions of The States of Malaysia. $2^{\text {nd }}$ Edition. (Kuala Lumpur: International Law Book Services, 1998). 
Hukum Kanun Johor, Hukum Kanun Pahang, Hukum Kanun Perak, Undang-Undang Kedah, etc. ${ }^{23}$

The concept of the Sultan being the shadow of Allah s.w.t could include the Sultan and in the case of the Malay Rulers as the trustee of the authority that belongs to Allah s.w.t. ${ }^{24}$ This position placed a divine responsibility upon the Malay Rulers to uphold the principle of Islamic law in their rulings and the same principle continued to be enforceable upon those who perform their executive, legislative as well as judicial functions equally. ${ }^{25}$ The responsibility to uphold the above principle is encumbered upon them since the principle of sovereignty inherited by virtue of Article 181(1) read together with the oath of Yang di-Pertuan Agong and Article 3(1) stipulated as such. There are many other constitutional provisions further supporting the above legal injunction amongst others is the oath under the Sixth Schedule taken up by a member of administration, parliament and judiciary. The notion of the

23 Read Wan Ahmad Fauzi Wan Husain. Kedaulatan Raja-Raja

24 Kedaulatan Raja-Raja Melayu: Jurisprudens, Governan \& Prinsip Perlembagaan Persekutuan (Selangor: Abad Sinergi Sdn. Bhd., 2018); Ph. S. Van Ronkel. Risalat Hoekoem Kanoen: Jaitoe Oendang-Oendang Melaka (Leiden: E. J. Brill, 1919); Yaakub Isa. Hukum Kanun Pahang (Pahang: Lembaga Muzium Negeri Pahang, 2003); Liaw, Yock Fang (pngr.) Undang-Undang Melaka. (Kuala Lumpur: Yayasan Karyawan, 2003); Preface to the Pahang Code of Laws (Pahang Museum Manuscript version, 2003, 3-4) translated as follows, "And after that, I have thanked Him for His past Grace and that which is to come. That He may make me from the people of His beloved and the people of the Leader of all His messengers whom He commanded He brought all His words and canons of the previous prophet by doing justice and doing Amar bil-ma'ruf wa nahiya al-Munkar then so enlighten all these worlds with the light of their religion. Peace be upon him and all his family and all his friends and all his people. Thereafter, then He made some among all His creatures, kings; as His Glorious Word says: Inni jaa'ilun fi al-ardzi Khalifah. Haza fi arrisalati yahkumu al-qanun fil-Burhani-fa al-Malki al-Kabir wa al-wazir. Amma ba'd'.

25 Ibid; Wan Ahmad Fauzi Wan Husain. Kedaulatan Raja-Raja Melayu: Jurisprudens, Governan \& Prinsip Perlembagaan Persekutuan (Selangor: Abad Sinergi Sdn. Bhd., 2018), p. 280-312. 
sovereignty of the Malay Rulers had been recognized by Western scholars such as Stockwell. Stockwell ${ }^{26}$ found:

Traditionally, the Malay Rulers are regarded as the source of all laws, heads of government, and religions. His Majesty is responsible for maintaining customs and the Malay community structures. However, his power may be implemented by the other party, and the other party may carry out duties or advise the king with its policies, but the legitimacy of all authoritative actions lies with the sovereignty of the Malay Rulers.

The above local circumstances evidenced the application of the continuum philosophical legal framework in the traditional political system. The continuum framework based on the words of the Almighty Allah in Surah al-Ma'idah (5:48):

To thee, We sent the Scripture in truth confirming the scripture that came before it and guarding it in safety; so judge between them by what God hath revealed and follow not their vain desires diverging from the Truth that hath come to thee. To each of you have We prescribed a Law and an Open Way. If God had so willed, He would have made you a single people but (His plan is) to test you in what He hath given you: so strive as in a race in all virtues. The goal of you all is to God; it is He that will show you the truth of the matters in which ye dispute."

The interpretation given for the above verse by Islamic Foundation $\mathrm{UK}^{27}$ is as follows:

This points to a fact of major significance. It could also have been said that the Qur'an confirms all those parts of the earlier divine books which are still extant in their true and original form. But the sense has been conveyed by employing the word 'the Book' rather than 'the previous Books'. This expression reveals that the Qur'an and all those Books sent down by God at various times and in different languages in reality constitute one and the same Book. Their Author is one and the same; their aim and purpose are the same; their teaching is the same; and the knowledge which they seek to impart to mankind is the same. The difference between these Books lies in their modes of expression, and this was necessarily so

26 Stockwell Stockwell, A.J., British Policy, and Malay Politics during the Malayan Union Experiment 1942-1948 (Monograph No. 8. Kuala Lumpur: Malayan Branch of the Royal Asiatic Society, 1979), p. 75.

27 Islamic Foundation UK. Towards Understanding the Qur'an. Islamicstudies.info (retrieved on 21 June 2021). 
since they were addressed to different audiences. It is, therefore, not merely that these divine books support rather than contradict each other but that they are actually different editions of one and the same book - 'the Book'.

It should be noted that throughout the British intervention in Tanah Melayu, the constitutional position of the Malay rulers being a caliph was never touched, let alone repealed. The British only introduced administrative policies and the justice system through the doctrine of advice but their validity was sourced from the authority laid with the Malay Rulers. Upon examining many provisions in the various agreements or treaties signed by the Malay Rulers with the British government, there was no restriction imposed therein to curtail the practice of Islamic legal principles. The reception of English common law and rules of equity in the Malay states were enforceable only so far as the circumstances and their inhabitants permit and subject to qualification as local circumstances render necessary. ${ }^{28}$

In the meantime, it must be observed that the reception of English common law, rules of equity, local legislations, and administrative policies introduced in the local legal system were subject to the traditional constitutional law of the respective Malay states that embraced the doctrine of Sultan being the shadow of Allah s.w.t. ${ }^{29}$ The development of the public aspect of Islam under the advice

28 Civil Law Enactment No. 3 of 1937 for the Federated Malay States, this principle was only applicable in other States according to Civil Law (Extension) Ordinance No. 49/1951. For a legal argument on the implication of the principle of indigenous sovereignty sourced from the Islam religion upon the reception of the English common law and the rules of equity please read Wan Ahmad Fauzi Wan Husain, Kedaulatan RajaRaja Melayu: Jurisprudens, Governan \& Prinsip Perlembagaan Persekutuan (Selangor: Abad Sinergi Sdn. Bhd., 2018), 294-310.

29 Section 3 of the Civil Law Act 1956 (Revised 1972); Wan Ahmad Fauzi Wan Husain. Yang di-Pertuan Agong: Kedaulatan, Prerogatif dan Amalan (Kuala Lumpur: Dewan Bahasa dan Pustaka, 2021), 113-117; Preface to the Pahang Code of Laws (Pahang Museum Manuscript version, 2003, 3 4) translated as follows, "And after that, I have thanked Him for His past Grace and that which is to come. That He may make me from the people of His beloved and the people of the Leader of all His messengers whom He commanded He brought all His words and canons of the previous prophet by doing justice and doing Amar bil-ma'ruf wa nahiya al-Munkar then so enlighten all these worlds with the light of their religion. Peace be 
of British officers thereafter did not alter the position of the Sultan being the shadow of Allah s.w.t. The salutation of Daulat Tuanku had been a Malay custom before the British interference in the internal affairs of the Malay states and remained thereafter. The Malay Rulers had never ascribed the sovereignty for themselves, but maintained the position as the head of Islam religion vis-à-vis a Caliph. ${ }^{30}$

Like the English Constitution, ${ }^{31}$ constitutional principles of the Malay traditional political system were one codified in a single reference only. Besides the written laws named after hukum kanun and undang-undang such as Hukum Kanun Melaka, Hukum Kanun Johor, Hukum Kanun Pahang, Hukum Kanun Perak, Undang-Undang 99 Perak, Undang-Undang Kedah, ones that must be read together with the principles of Islamic law and unwritten Malay custom. ${ }^{32}$ Various

upon him and all his family and all his friends and all his people. Thereafter, then He made some among all His creatures, kings; as His Glorious Word says: Inni jaa'ilun fi al-ardzi Khalifah. Haza fi ar-risalati yahkumu al-qanun fil-Burhani - fa al-Malki al-Kabir wa al-wazir. Amma ba'd".

30 Ibid; Muhammad Yusoff Hashim. Edisi kedua. Kesultanan Melayu Melaka (Kuala Lumpur: Dewan Bahasa dan Pustaka 2015), 239-241; Wan Ahmad Fauzi Wan Husain. Yang di-Pertuan Agong: Kedaulatan, Prerogatif dan Amalan (Kuala Lumpur: Dewan Bahasa dan Pustaka, 2021), 146-181; Raja Ali Haji. Thamarat al-Muhimmah Diyafah li alUmara wa al-Kubara' li Ahl al-Mahkamah. (Lingga: Pejabat Kerajaan Lingga, 1886).

31 The British constitution is also peculiar compared to the other countries in the World. It is not codified into a single document where its reference is taken from statutes, common laws, and conventions of the Westminster.

32 Written Malay custom is the one stipulated in various hukum kanun and other legal documents, on the other hand, the unwritten ones were those practiced and accepted as authoritative in the respective Malay states. The written Malay custom could be referred inter alia to Ph. S. Van Ronkel. Risalat Hoekoem Kanoen: Jaitoe Oendang-Oendang Melaka (Leiden: E. J. Brill, 1919); Liaw, Yock Fang (pngr.) Undang-Undang Melaka. (Kuala Lumpur: Yayasan Karyawan, 2003); Yaakub Isa. Hukum Kanun Pahang (Pahang: Lembaga Muzium Negeri Pahang, 2003) Those constitutional principles not stipulated in the written laws could be sourced inter alia in Raja Ali Haji. Thamarat al-Muhimmah Diyafah li al-Umara wa alKubara' li Ahl al-Mahkamah. (Lingga: Pejabat Kerajaan Lingga, 1886); A. Samad Ahmad (pngr.). Sejarah Melayu (Kuala Lumpur: Dewan Bahasa dan Pustaka, 1986); Tun Seri Lanang. Sulalat Al-Salatin. 
laws such as the laws of contract, evidence, and criminal are also embodied in the said hukum kanun. ${ }^{33}$ Based upon the constitutional law and practices in the Malay states before 1948 as well as from the legal historical context sourced from those valid sources in the form of traditional written constitutions found in the Malay states as enumerated above, the basic structure of the traditional constitutions were evidenced ${ }^{34}$ as follows:

1. Sultan was a sovereign head of state positioned as the shadow of the Almighty Allah on the earth.

2. Sultan must be a Muslim and regarded as the head of Islam religion.

3. The appointment of a Sultan would be followed by the Oath of Fealty (Bai'ah) upon the decision of the Ruler's Council (Syura).

4. Islamic law was practiced and became the law of the land.

5. Sources of the constitutional law were Malay custom and Islamic principles of law. ${ }^{35}$

6. Islamic legal principles were adopted in Malay custom. Malay custom formed part of local legislation besides Islamic laws. ${ }^{36}$

Muhammad Salleh (pngr.). (Kuala Lumpur: Yayasan Karyawan \& Dewan Bahasa dan Pustaka, 1997).

33 Liaw, Yock Fang (pngr.) Undang-Undang Melaka. (Kuala Lumpur: Yayasan Karyawan, 2003), p. 61-71; Read Ph. S. Van Ronkel. Risalat Hoekoem Kanoen: Jaitoe Oendang-Oendang Melaka (Leiden: E. J. Brill, 1919).

34 Ibid.

35 Article 160(2) of the Federal Constitution defines "written law" which includes the Federal Constitution and the Constitution of any State; where "law" includes written law, the common law in so far as it is in operation in the Federation or any part thereof, and any custom or usage having the force of law in the Federation or any part thereof; Read Wan Ahmad Fauzi Wan Husain. Yang di-Pertuan Agong: Kedaulatan, Prerogatif dan Amalan (Kuala Lumpur: Dewan Bahasa dan Pustaka, 2021), p. 89-101 for further clarification; Article 162 of the Federal Constitution stipulates the application of the existing laws in Malaya.

36 The source of Malay custom was from the authority of the Malay rulers whose position as the shadow of the Almighty Allah as evidenced in the written law such as Hukum Kanun Melaka and Hukum Kanun Pahang as amongst others evidenced in Preface to the Pahang Code of Laws (Pahang 
7. Sultans and their officers were answerable to the Almighty Allah for rule-following Islamic legal principles and Malay custom with the responsibility to uphold justice in their administration.

8. The appointment of legislative, executive, and judicial posts was done following Malay custom.

9. The practice of Syura is pursued in enacting policies and deciding important matters. The majority votes were part of the system but subject to Islamic legal principles.

10.Every Malay state had a court hierarchy with competent jurisdiction to try all criminal and civil cases based upon Islamic laws, Islamic legal principles, and Malay custom.

11.Courts under the State administration including Mahkamah Balai $^{37}$ dan Syariah Courts ${ }^{38}$ had been in existence long before the introduction of the modern form of the state constitution and

Museum Manuscript version, 2003, 3-4) translated as follows, “And after that, I have thanked Him for His past Grace and that which is to come. That He may make me from the people of His beloved and the people of the Leader of all His messengers whom He commanded He brought all His words and canons of the previous prophet by doing justice and doing Amar bil-ma'ruf wa nahiya al-Munkar then so enlighten all these worlds with the light of their religion. Peace be upon him and all his family and all his friends and all his people. Thereafter, then He made some among all His creatures, kings; as His Glorious Word says: Inni jaa'ilun fi alardzi Khalifah. Haza fi ar-risalati yahkumu al-qanun fil-Burhani-fa alMalki al-Kabir wa al-wazir. Amma ba'd".

37 Adjudicating any dispute and administering justice in criminal as well as civil jurisdiction based upon hukum Syarak dan Malay custom, reference made from the book of Minhaj al-Tolibin, hudud offences were enforceable (Muhammad Yusuff Hashim, Terengganu Darul Iman: Tradisi Persejarahan Malaysia, Kuala Lumpur: Dewan Bahasa dan Pustaka, 1991, 137 dan 390; Undang-Undang Tertib Mahkamah Terengganu, Bil-4 Tahun 1304H (1921M) stipulated the jurisdiction for Mahkamah Apil, Mahkamah Besar, Mahkamah Majistret Pangkat I, Mahkamah Majistret Pangkat II, Mahkamah Qadi and Mahkamah Penghulu.

38 Adjudicating ritual and marriage cases (ibid). 
the establishment of the judicial power of the Federation under Article 121 of the Federal Constitution ${ }^{39}$.

12.During the British advisory system in the Malay states, local legislations were introduced besides the application of Islamic law and Malay custom.

13.The position of sultans as the vicegerent of Allah s.w.t was never affected throughout the British interference in the Malay states. ${ }^{40}$

Taj us-Salatin, Bustan al-Salatin, Tuhfat al-Nafis, Muqaddimah fi Intizam al-Wazaif al-Muluk, Thammarat al-Muhimmah Diyafah li alUmara 'wa al-Kubara 'li-Ahl al-Mahkamah and Gurindam Dua Belas become the living evidence until today of how the constitutional system sourced from the Islam religion and Malay custom were then developed. The other elements represented the features of the traditional constitution of the day before Merdeka Day were as follows:

1. Islam and Malay Sultanates were the core elements of the Malay identity. ${ }^{41}$

2. The Malay language was "a lingua-franca" for the Malay Archipelago and the official language for the Malay sultanates. ${ }^{42}$

3. Jawi was writing form for the Malay language. ${ }^{43}$

39 By 1909, there were two hierarchal courts in Kuala Terengganu, Mahkamah Balai dan Syariah Court, both had own judges that possessed required expertise in the Islamic laws. Later the Syariah Court was named after the First-Class Magistrate's Court (Pentadbiran Hal Ehwal Islam Negeri Terengganu: Sejarah dan Perkembangannya Hingga Kini- 2013, Kuala Terengganu: Majlis Agama Islam dan Adat Melayu Terengganu, 2014), 55.

40 Wan Ahmad Fauzi Wan Husain, Kedaulatan Raja-Raja Melayu: Jurisprudens, Governan \& Prinsip Perlembagaan Persekutuan (Selangor: Abad Sinergi Sdn. Bhd., 2018), 216-246.

41 Wan Ahmad Fauzi Wan Husain, YB Datuk. 2013. Rekonfigurasi Epistemologi Jati Diri Melayu dan Manifestasinya ke Atas Silat Seni Gayong. Disertasi Sarjana Falsafah, Universiti Kebangsaan Malaysia.

42 Ibid; Zainal Abidin Abdul Wahid. 1990. Kerajaan Melaka dalam Hubungan Antarabangsa. Jebat, 18: 71-87; Perjanjian Persekutuan Tanah Melayu 1948.

43 Ibid; A. Samad Ahmad (pngr.). Sejarah Melayu (Kuala Lumpur: Dewan Bahasa dan Pustaka, 1986); Tun Seri Lanang. Sulalat Al-Salatin. 
4. Malays and aborigines of Tanah Melayu were the subjects of the Malay rulers ${ }^{44}$.

The independence of the Malay States continued to be recognized in the Proclamation of Independence Ceremony-Lowering of Union Jack ${ }^{45}$ which stated, "That the Malay States never having been British territory but only British protected territory, the British flag cannot be lowered since it has never been raised".

\section{UNAMENDABLE CONSTITUTIONAL PROVISIONS BY PARLIAMENT}

The Federal Constitution of Malaya came into force on 31 August 1957 that institutionalized a federation of nine Malay States with two Straits Settlements. The Federation of Malaya consisted of Johor, Kedah, Kelantan, Negeri Sembilan, Pahang, Perak, Perlis, Selangor, Terengganu, Melaka, and Pulau Pinang. Malaysia was later established after the Federation of Malaya admitting Singapore, Sabah, and Sarawak on 16 September $1963 .^{46}$

Several express constitutional provisions duly safeguarded from any amendments by Parliament alone. Those provisions fall under Articles 38(4) and 159(5) of the Federal Constitution, 1957 ${ }^{47}$. Article

Muhammad Salleh (pngr.). (Kuala Lumpur: Yayasan Karyawan \& Dewan Bahasa dan Pustaka, 1997);

44 The equal term used today is citizenship or nationality: Federation Agreement of Malaya, 1948.

45 Organizing Committee Letter dated 18 July 1957.

46 Singapore was removed from Malaysia in 1965.

47 The new provision of Article 161E was inserted in 1963 to protect the constitutional position of Sabah and Sarawak. Article 161E reads:

(1) As from the passing of the Malaysia Act, no amendment to the Constitution made in connection with the admission to the Federation of the State of Sabah or Sarawak shall be excepted from Clause (3) of Article 159 by paragraph $(b b)$ of Clause (4) of that Article; nor shall any modification made as to the application of the Constitution to the State of Sabah or Sarawak be so excepted unless the modification is such as to equate or assimilate the position of that State under the Constitution to the position of the States of Malaya.

(2) no amendment shall be made to the Constitution without the concurrence of the Yang di-Pertua Negeri of the State of Sabah or Sarawak or each of 
38(4) states, "no law directly affecting the privileges, position, honours or dignities of the Rulers shall be passed without the consent of the Conference of Rulers". Besides, thereto, Article 159(5) states:

A law making an amendment to Clause (4) of Article 10, any law passed thereunder, the provisions of part III, Article 38, Clause (4)

the States of Sabah and Sarawak concerned if the amendment is such as to affect the operation of the Constitution as regards any of the following matters:

(a) the right of persons born before Malaysia Day to citizenship by reason of a connection with the State, and (except to the extent that different provision is made by the Constitution as in force on Malaysia Day) the equal treatment, as regards their own citizenship and that of others, of persons born or a resident in the State and of persons born or a resident in the States of Malaya;

(b) the constitution and jurisdiction of the High Court in Sabah and Sarawak and the appointment, removal, and suspension of judges of that court;

(c) the matters with respect to which the Legislature of the State may (or parliament may not) make laws, and the executive authority of the State in those matters, and (so far as related thereto) the financial arrangements between the Federation and the State;

(d) religion in the State, the use in the State or parliament of any language and the special treatment of natives of the State;

(e) the allocation to the State, in any parliament, summoned to meet before the end of August 1970, of a quota of members of the house of Representatives not less, in proportion to the total allocated to the other States which are members of the Federation on Malaysia Day, than the quota allocated to the State on that Day.

(3) no amendment to the Constitution which affects its operation as regards the quota of members of the house of Representatives allocated to the State of Sabah or Sarawak shall be treated for purposes of Clause (1) as equating or assimilating the position of that State to the position of the States of Malaya.

(4) in relation to any rights and powers conferred by federal law on the Government of the State of Sabah or Sarawak as regards entry into the State and residence in the State and matters connected therewith (whether or not the law is passed before Malaysia Day) Clause (2) shall apply, except in so far as the law provides to the contrary, as if the law had been embodied in the Constitution and those rights and powers had been included among the matters mentioned in paragraphs $(a)$ to $(e)$ of that Clause.

(5) In this Article "amendment" includes addition and repeal. 
of Article 63, Article 70, Clause (1) of Article 71, Clause (4) of Article 72, Article 152, or 153 or to this Clause shall not be passed without the consent of the Conference of Rulers.

The above Articles are concerning the following subjects:

1. Law imposing restrictions in the interest of the security of the Federation or any part thereof or public order under paragraph (a) of Article 10(2). Parliament may pass a law prohibiting the questioning of any matter, right, status, position, privilege, sovereignty, or prerogative established or protected by the provisions of Part III, Article 152, 153 or 181 otherwise than in relation to the implementation thereof as may be specified in such law.

2. Part III touches on the subject of citizenship.

3. Article 38 is on the establishment and functions of the Conference of Rulers.

4. Clause (4) of Article 63 and Clause (4) of Article 72 are the limitation for privileges in Parliament as well as Legislative Assemblies proceedings against offenses under the law passed by parliament under Clause (4) of Article 10 or with an offense under the Sedition Act 1948.

5. Article 70(1) is on the precedence of the Yang di-Pertuan Agong and his Consort, the Rulers, and Yang di-Pertua-Yang di-Pertua Negeri of the States among themselves.

6. Article 71(1) is about the Federal guarantee of State Constitution with regard to the right of a Ruler of a State to succeed and to hold, enjoy and exercise the constitutional rights and privileges of Ruler of that State in accordance with the Constitution of that State, and any dispute as to the title to the succession as Ruler of any State.

7. Article 152 is on the position of Bahasa Melayu as the National language as well as Jawi writing as protected under the National Language Act 163/76 Revised 1971) made thereunder.

8. Article 153 is on the reservation of quotas in respect of services, permit, etc for Malays and natives of any states of Sabah and Sarawak.

9. Article 195(5) itself. 
The above provisions are only capable of being amended with the express consent of the Conference of Rulers being obtained. The above principle that curtails the amending power of Parliament expressly denies the doctrine of parliamentary sovereignty vis-à-vis an absolute democracy notion in our constitutional framework. On the contrary, the express provision of Article 181(1) that proclaims the sovereignty of the Malay rulers bearing the characteristics as the trustee of Allah swt. ${ }^{48}$ It is worth noting that certain elements as aforesaid are firmly protected even during a period of emergency. Article 150(6A) states:

Clause (5) shall not extend the powers of parliament with respect to any matter of Islamic law or the custom of the Malays, or with respect to any matter of native law or customs in the State of Sabah or Sarawak; nor shall Clause (6) validate any provision inconsistent with the provisions of this Constitution relating to any such matter or relating to religion, citizenship, or language.

In short, the aforesaid unamendable provisions by the Parliament alone are entrenched in the strongest protection under our Federal Constitution. Those are the local elements that mainly originated from our sovereign national history that is placed under close scrutiny and purview of the Conference of Rulers.

\section{TEXTUAL AND PHILOSOPHICAL ASPECTS OF THE CONSTITUTIONAL PROVISIONS IN HISTORICAL CONTEXT}

The Constitutional Working Committee Report 1946, ${ }^{49}$ states that the sovereignty in each of the Malay State shall rest as heretofore on His Highness the Ruler of that state according to Malay custom. As such, Malay custom is the legal underlying principle of the federal constitutional system. Malay custom is defined as manners, culture and existing law together with commandments revealed in the Quran and

48 See Articles 3, 11, 12, 37, 71(1), 150(6A) and 162 of the Federal Constitution. Read Wan Ahmad Fauzi Wan Husain. Yang di-Pertuan Agong: Kedaulatan, Prerogatif dan Amalan (Kuala Lumpur: Dewan Bahasa dan Pustaka, 2021); Wan Ahmad Fauzi Wan Husain. Kedaulatan Raja-Raja Melayu: Jurisprudens, Governan \& Prinsip Perlembagaan Persekutuan (Selangor: Abad Sinergi Sdn. Bhd., 2018).

49 C.O 537/1530 No. 50823 Part III (Colonies, General: Supplementary and Secret Original Correspondence, 18 November 1946). 
Sunnah; which includes the systems, rules, ethics and values that do not conflict with the principles of Islam as inherited from the practices of the Malay society and the Malay government in the past. Malay custom also includes the traditional political and legal systems. ${ }^{50}$

It is submitted that Malay custom as presented here, legitimizes the principles of Syariah compliance and prevails over the application of Common Law and rules of equity. In a broad and purposive manner as promulgated in the Canadian Supreme Court in Reference re Senate Reform, Malay custom curtails the powers of the judiciary exercisable by judges administering federal laws as well as state law. The principle under federal law is found in Section 3, Civil Law Act 1956 (Revised 1972). Section 3 stipulates:

3(1) Save so far as other provision has been made or may hereafter be made by any written law in force in Malaysia, the Court shall--

(a) in Peninsular Malaysia or any part thereof, apply the common law of England and the rules of equity as administered in England on the 7 April 1956;

(b) in Sabah, apply the common law of England and the rules of equity, together with statutes of general application, as administered or in force in England on 1 December 1951;

(c) in Sarawak, apply the common law of England and the rules of equity, together with statutes of general application, as administered or in force in England on 12 December 1949, subject however to subparagraph (3)(ii):

Provided always that the said common law, rules of equity, and statutes of general application shall be applied so far only as the circumstances of the States of Malaysia and their respective inhabitants permit and subject to such qualifications as local circumstances render necessary.

The principle of Malay custom as defined above is still applicable within our constitutional framework. The interpretation of the law under Article 160(2) includes "written law, the common law in so far as it is in operation in the Federation or any part thereof, and any custom or usage having the force of law in the Federation or any part thereof". Written law is defined in our Federal Constitution to include

50 Wan Ahmad Fauzi Wan Husain, Kenegaraan Malaysia: Sejarah, Kedaulatan dan Kebangsaan (Perlis: Penerbit Universiti Malaysia Perlis, 2020), 29-31. 
the Federal and constitution of any state. ${ }^{51}$ The traditional constitutional laws in Malaya are law and written law pursuant to the above interpretation. Those written laws such as Hukum Kanun Melaka, Hukum Kanun Johor, Hukum Kanun Pahang, and many others still survive, pursuant to Article 162 of Part XIII ${ }^{52}$ of the Federal Constitution. Existing laws means, "any law in operation in the Federation or any part thereof immediately before Merdeka Day". There is no evidence that the said existing laws such as Hukum Kanun Johor, Hukum Kanun Pahang, Undang-Undang 99 Perak, and Undang-Undang Kedah had ever been repealed before Merdeka Day. Article 162(1) states:

Subject to the following provisions of this Article and Article 163 , the existing laws shall, until repealed by the authority having the power to do so under this Constitution, continue in force on and after Merdeka Day, with such modifications as may be made therein under this Article and subject to any amendments made by federal or State law.

The existing laws are capable of being enforced with such modifications in the manner as stipulated in Article 162(6). Article 162(6) states:

Any court or tribunal applying the provision of any existing law which has not been modified on or after Merdeka Day under this Article or otherwise may apply it with such modifications as may be necessary to bring it into accord with the provisions of this Constitution".

Such modifications include those relating to the issue of jurisdiction to make law under the Ninth Schedule of the Federal Constitution. The interpretation of federal law, as well as state law under Article 160(2), here bears the meaning of any existing law relating to a matter with respect to which Parliament has the power to make laws, being a law continued in operation under part XIII; and any existing law relating to a matter with respect to which the Legislature of a State has power to make law, being a law continued in operation under part XIII.

According to the Federation Agreement of Malaya, 1957 the sovereignty of Pulau Pinang and Melaka being two states of the Straits Settlements were handed over to the Yang di-Pertuan Agong being the

51 Article 160(2).

52 Part XIII contains Articles 161 until 180 of the Federal Constitution. 
head of the Federal authority. ${ }^{53}$ The sovereignty of the Malay states remained in their respective rulers with certain authority and jurisdiction delegated to the Yang di-Pertuan Agong in the manner expressly provided by constitutional provisions.

In the Federal Constitution, sovereignty is expressly stipulated in Article 181(1). Article 181(1) proclaims the sovereignty of the Malay Rulers. The same principle of sovereignty is expressly stipulated in their respective state constitutions. The principle of sovereignty of the Yang di-Pertuan Agong is laid down in the oath of his office in the Fourth Schedule of the Federal Constitution. Such principle attributes of sovereignty attached with the Yang di-Pertuan Agong is in the form of trust, thus, corresponds with the position as the shadow of the Almighty Allah or a caliph. ${ }^{54}$ The characteristics of sovereignty in the Federal Constitution must be read together with the position of Islam ${ }^{55}$ and the rights of Muslims to practice their religion in the Federal Constitution. The notion of the shadow of the Almighty Allah itself sustains the characteristic of the Yang di-Pertuan Agong and the Malay rulers as heretofore submitted.

The Yang di-Pertuan Agong is the source of authorities and jurisdiction as specified in the Ninth Schedule, List I and III of the Federal Constitution. He represents the Malay Rulers to rule the

53 Clause 3 of the Federation of Malaya Agreement 1957, which states:

As from the thirty-first of August, nineteen hundred and fifty-seven, the Malay States and Settlements shall be formed into a new federation of States by the name of Persekutuan Tanah Melayu, or in English, the Federation of Malaya, under the Federal Constitution set out in the First Schedule to this Agreement; and thereupon the said Settlement shall cease to form part of Her Majesty's dominions and Her Majesty shall cease to exercise any sovereignty over them, and all powers and jurisdiction of Her Majesty or the Parliament of the United Kingdom in or in respect of the Settlements or the Malay States or the Federation as a whole shall come to an end.

54 Wan Ahmad Fauzi Wan Husain. Yang di-Pertuan Agong: Kedaulatan, Prerogatif dan Amalan (Kuala Lumpur: Dewan Bahasa dan Pustaka, 2021), 146-181; Wan Ahmad Fauzi Wan Husain. Kedaulatan Raja-Raja Melayu: Jurisprudens, Governan \& Prinsip Perlembagaan Persekutuan (Selangor: Abad Sinergi Sdn. Bhd., 2018), 280-312.

55 Ibid; Read Wan Ahmad Fauzi Wan Husain. "The Interpretation of Islam within the Framework of the Indigenous Malaya. " Journal of Governance and Integrity, Vol. 4, Issue 2, July 2, 2021); 
Federation. Those authorities are only exercisable under the constitutional provisions and after he has taken and subscribed to the Oath of office ${ }^{56}$. The Yang di-Pertuan Agong is vested with the executive authority of the Federation. ${ }^{57}$ The Yang di-Pertuan Agong is the highest entity of the Parliament besides Dewan Rakyat and Dewan Negara being the Federal legislative power. ${ }^{58}$ The federal justice system is administered in the name of the Yang di-Pertuan Agong where judicial appointments are made by him in the manner stipulated in the Federal Constitution.

Any person that exercises legislative, executive, and judicial functions must act in conformity with the oath of the Yang di-Pertuan Agong ${ }^{59}$. The Oath of office of the Yang di-Pertuan Agong ${ }^{60}$ reads:

We shall justly and faithfully perform (carry out) our duties in the administration of Malaysia in accordance with its laws and Constitution which have been promulgated or which may be promulgated from time to time in the future. Further, we do solemnly and truly declare that we shall at all time protect the Religion of Islam and uphold the rules of law and order in the Country

From the point of view of being a Muslim, the Malay rulers are duty bound to obey the commands of the Almighty Allah, let alone those in position as the head of religion and supreme leader. The Almighty Allah dictates the responsibility of a ruler as follows ${ }^{61}$ :

We ordained therein for them: "Life for life eye for eye nose for nose ear for ear tooth for tooth and wounds equal for equal". But if anyone remits the retaliation by way of charity it is an act of

\footnotetext{
56 Article 37 of the Federal Constitution.

57 Article 39 of the Federal Constitution.

58 Article 44 of the Federal Constitution.

59 They are persons required to subscribe to the Oath under the Sixth Schedule, which reads:

$\mathrm{I}, \ldots . .$. having been elected (or appointed) as a member of the House of Representatives (or the Senate) do solemnly swear (or affirm) that I will faithfully discharge my duties as such to the best of my ability, that I will bear true faith and allegiance to Malaysia, and will preserve, protect and defend its Constitution.

60 The Fourth Schedule, Federal Constitution.

61 Surah al-Ma'idah (5:45).
} 
atonement for himself. And if any fail to judge by (the light of) what God hath revealed they are (no better than) wrong-doers.

\section{RECOMMENDATIONS AND CONCLUSION}

In the Malaysian context, the indigenous sovereignty that positioned a Malay ruler as the shadow of the Almighty Allah or caliph was strongly embedded as intrinsic to and arises from, the very nature of the basic structure of the traditional constitution of the Malay states that constructed the Federal Constitution of the then Malaya. That intrinsic structure had come together with the other essential elements as enumerated, establishing the foundation of the Malaysian federalism and placed in the strongest protection under the personal purview of the Conference of Rulers as stipulated under Article 38(4), Article 159(5) and further entrenched with Article 150(6A).

Those elements enumerated as the position of Islam, Malay rulers, citizenship, federalism, Malay language, special position of the Malay and natives of any of Sabah and Sarawak, and Malay custom are the basic structure of the Federal Constitution upon given to a broad and purposive manner in proper linguistic, philosophic, and historical contexts of the Malaysian legal historical documents. They are not capable of being amended by the Parliament alone. Article 161E is incorporated in the Federal Constitution in order to protect the commitment given in the Malaysian Agreement 1963 without affecting the position of those initially enumerated in Article 38(4) and Article 159(5).

Hence, the ultimate principles of the basic structure are as embedded in the Oath of office of the Yang di-Pertuan Agong together with the matters aggregated in Article 38(4), Article 159(5), and Article 161E. The oath of the Yang di-Pertuan Agong upholds the principle of sovereignty within the constitutional framework that legitimizes Syariah compliance as the rule of law.

In conclusion, such legal framework as aforesaid does not permit the Court to arbitrarily import external elements that are inconsistent with our local circumstances and bear any interpretation of the law that are against the principle of Syariah both in federal and state jurisdiction, without exception to the same duty placed upon every member of the executive and legislative organs that subscribe to the oath under the Sixth Schedule. 